\title{
Surfactant Residues in Maryland Tobacco Treated with a Fatty-Alcohol-Type Sucker-Control Formulation *
}

\author{
by Amber L. S. Cheng and G. L. Steffens \\ Tobacco Laboratory and Plant Hormone Laboratory, Beltsville Agricultural Research Center, \\ Agricultural Research Service, U.S. Department of Agriculture, Beltsville, Maryland, U.S.A.
}

\section{INTRODUCTION}

Fatty alcohols of C-8 and C-10 chain lengths are used to inhibit the growth of axillary buds (suckers) in the commercial production of tobacco (1). Emulsions of the fatty alcohols formulated with the proper amount and type of surfactant (2) selectively inhibit or kill young tobacco suckers on contact, but have no effect on the more mature, commercially valuable leaves. The fattyalcohol contact-type sucker-control agents have been extensively studied in various tobacco-producing areas for their efficacy and effects on leaf quality $(3,4,5,6)$. Surfactants widely used in the preparation of commercial formulations of the fatty alcohols are polyoxyethylene[20]sorbitan monooleate [Tween 80] and closely related products (2). These surfactants are complex mixtures of polyoxyethylene ethers of mixed partial oleic esters of sorbitol anhydrides. Besides containing these mixed-function derivatives, the surfactants also contain free polyoxyethylene. Previous studies (7) with Tween 80-- ${ }^{14} \mathrm{C}-1$-fatty acid and ${ }^{14} \mathrm{C}-\mathrm{U}^{* *}$-ethylene oxide applied to various classes of field-grown tobacco have shown that calculated residue levels ranged from about 0.41 to $1.45 \mathrm{ppm}$. These levels may reflect the residues of either the mixed-function derivatives or the free polyoxyethylene, depending on whether the label was on the fatty-acid moiety or on ethylene oxide. Further studies by $\mathrm{Tso}_{\mathrm{S}}$ and $\mathrm{Cbu}$ (8) showed that most of the residue from Tween 80 applied on field-grown tobacco was hydrolyzed to free polyols and fatty acids. The study reported here was undertaken to monitor polyoxyethylene[20]sorbitan monooleate [Tween 80] residues remaining on green and cured tobacco leaf treated with a sucker-control agent formulated with this surfactant.

\footnotetext{
* Received: 27th April 1982 - accepted: 13th September 1982.

Reference to a company or product aame does not imply approval or recommendation by the United States Department of Agriculture.
}

\section{EXPERIMENTAL}

\section{Materials and Methods}

Plant Material: Nicotiana tabacum L. cv. "Maryland 10" was grown at Beltsville, Maryland, by conventional cultural practices. Sucker-control chemicals were applied to plants which had been decapitated or topped after they had reached mid-bloom. The spray formulation was an emulsion consisting of a mixture of 1-octanol and 1-decanol (approximately $45 \% \mathrm{C}-8$ and $55 \% \mathrm{C}-10$ ), with polyoxyethylene[20]sorbitan monooleate [Tween $80]$ as the surfactant. The emulsion was applied at the rate of $30 \mathrm{ml} /$ plant with a shoulder-type sprayer, so that a coarse spray was directed downward over the stalk and leaves.

Three experiments were conducted:

Experiment No. 1: The purpose of this experiment was to ascertain the levels of Tween 80 in field-grown tobacco between the time of treatment and harvest (14 days after treatment) and then after harvest during the curing period in the barn. Field-grown plants were treated with a preparation containing $4 \%$ of the 1-octanol plus 1-decanol formulation and $1 \%$ of Tween 80 (three replicates in a randomized block design). The fatty-alcohol treatment was followed by sprays containing maleic hydrazide [MH], 1,2-dihydro-3,6-pyridazinedione, applied at the rate of $3 \mathrm{lb} . / \mathrm{gal}$, as $\mathrm{MH}-30$ (170 mg active ingredient in $20 \mathrm{ml}$ of spray per plant). Top and bottom leaves were removed from the field-grown plants 1,7 and 14 days after treatment with the suckering agent and from stalks in the barn during the curing period 28,32 and 46 days after the treatment. Plants treated with $\mathrm{MH}$ alone were used as controls. The top and bottom leaves were

\#x uniformly labeled 
Table 1. Tween 80 resldues (ppm) on Maryland tobacco treated with a fatty-alcohol-type sucker-control spray.

\begin{tabular}{|c|c|c|c|c|}
\hline \multirow{2}{*}{$\begin{array}{l}\text { Days after } \\
\text { treatment }\end{array}$} & \multicolumn{2}{|c|}{ Tween 80 Esters } & \multicolumn{2}{|c|}{ Tween 80 free Polyols } \\
\hline & top leaf & bottom leaf & top leaf & bottom leaf \\
\hline \multicolumn{5}{|l|}{ Green leaf } \\
\hline 1 (Aug. 3) & $166.07 \mathrm{a}$ & $26.21 \mathrm{~cd}$ & $155.31 \mathrm{a}$ & 29.99 ef \\
\hline 7 (Aug. 10) & $68.95 b$ & $17.47 \mathrm{~d}$ & 49.42 bc & 31.03 def \\
\hline 14 (Aug. 17) & $60.41 \mathrm{~b}$ & $17.06 \mathrm{~d}$ & $48.00 \mathrm{bcd}$ & 32.86 cdef \\
\hline \multicolumn{5}{|l|}{ Air-cured } \\
\hline 28 (Aug. 31) & $63.93 \mathrm{~b}$ & $23.76 \mathrm{~cd}$ & $59.31 \mathrm{~b}$ & 41.75 cdef \\
\hline 32 (Sept. 14) & $34.26 \mathrm{~cd}$ & $23.16 \mathrm{~cd}$ & 43.18 bcdef & 33.88 cdef \\
\hline 46 (Sept. 29) & $42.86 \mathrm{C}$ & $18.71 \mathrm{~d}$ & 46.13 bcde & $27.24 f$ \\
\hline
\end{tabular}

1. Tween 80 Esters and free Polyols were statistically analyzed separately.

Values followed by the same letter within the same chemical are not significantly different at the 0.05 level (Duncan's multiple range test (13)).

2. Data were corrected for control.

Table 2. Tween 80 Ester and free Polyol residues (ppm) in Maryland tobacco during the first 24 hours after application of a contact-type sucker-control spray containing $1 \%$ Tween 80 .

\begin{tabular}{c|c|c|c|c|c|c}
\hline \multirow{2}{*}{ Hours } & \multicolumn{3}{|c|}{ Tween 80 Esters } & \multicolumn{2}{c}{ Tween 80 free Polyols } \\
\cline { 2 - 7 } & top leaf & bottom leaf & $\begin{array}{c}\text { upper half } \\
\text { stalk }\end{array}$ & top leaf & \multicolumn{2}{c}{$\begin{array}{c}\text { bottom leaf } \\
\text { upper half } \\
\text { stalk }\end{array}$} \\
\hline 0 & $666.82 \mathrm{a}$ & $42.05 \mathrm{~d}$ & $294.60 \mathrm{~b}$ & $412.82 \mathrm{a}$ & $31.87 \mathrm{~d}$ & $373.77 \mathrm{~b}$ \\
3 & $593.32 \mathrm{~b}$ & $33.87 \mathrm{~d}$ & $384.46 \mathrm{~b}$ & $264.30 \mathrm{~b}$ & $30.69 \mathrm{~d}$ & $425.90 \mathrm{~b}$ \\
6 & $693.69 \mathrm{a}$ & $63.44 \mathrm{~d}$ & $409.84 \mathrm{~b}$ & $287.63 \mathrm{~b}$ & $58.20 \mathrm{~d}$ & $411.19 \mathrm{~b}$ \\
24 & $209.43 \mathrm{C}$ & $20.28 \mathrm{~d}$ & $690.36 \mathrm{a}$ & $203.26 \mathrm{c}$ & $30.06 \mathrm{~d}$ & $635.32 \mathrm{a}$ \\
\hline
\end{tabular}

1. Tween 80 Esters and free Polyols were statistically analyzed separately.

Values followed by the seme letter within the same chemical are not significantly different at the 0.05 level (Duncan's multiple range test (13))

2. Data were corrected for control.

Table 3. Tween 80 Ester and free Polyol residues (ppm) in green (at harvest) and alr-cured Maryland tobacco leaves sprayed with a contact-type sucker-control agent containing either $0.68 \%$ or $1.36 \%$ Tween 80 .

\begin{tabular}{|c|c|c|c|c|c|c|}
\hline \multirow{2}{*}{$\begin{array}{l}\text { Tobacco } \\
\text { leaves }\end{array}$} & \multicolumn{3}{|c|}{ Tween 80 Esters } & \multicolumn{3}{|c|}{ Tween 80 free Polyols } \\
\hline & top leaf & bottom leaf & means & top leaf & bottom leaf & means \\
\hline \multicolumn{7}{|l|}{$0.68 \%$ Tween 80} \\
\hline Green & $32.95 \mathrm{c}$ & $22.52 d$ & 27.74 B & $171.81 \mathrm{a}$ & $78.40 \mathrm{c}$ & 125.11 B \\
\hline Air-cured & $18.59 \mathrm{de}$ & $15.96 \theta$ & $17.25 \mathrm{C}$ & $170.73 \mathrm{a}$ & $67.62 \mathrm{c}$ & $119.17 \mathrm{~B}$ \\
\hline Means & $25.77 \mathrm{~B}$ & $19.24 \mathrm{C}$ & $22.51 \mathrm{C}$ & $171.27 \mathrm{~A}$ & $73.01 \mathrm{C}$ & $122.14 \mathrm{~B}$ \\
\hline \multicolumn{7}{|l|}{$1.36 \%$ Tween 80} \\
\hline Green & $42.95 \mathrm{~b}$ & $49.38 \mathrm{a}$ & $46.17 \mathrm{~A}$ & $229.05 \mathrm{a}$ & $165.32 \mathrm{~b}$ & $197.18 \mathrm{~A}$ \\
\hline Air-cured & $31.56 \mathrm{c}$ & $33.20 \mathrm{c}$ & $32.38 \mathrm{~A}$ & $231.15 \mathrm{a}$ & $156.94 b$ & $194.08 \mathrm{~A}$ \\
\hline Means & $37.26 \mathrm{~A}$ & $41.29 \mathrm{~A}$ & $39.27 \mathrm{~A}$ & $230.10 \mathrm{~A}$ & $161.13 \mathrm{~A}$ & $195.61 \mathrm{~A}$ \\
\hline
\end{tabular}

1. Tween 80 Esters and free Polyols were statistically analyzed separately.

Values followed by the same letter within the same chemical are not significantly different at the 0.05 level (Duncan's multiple range test (13)).

2. Data were corrected for control. 
composited (two samples per replicate) and analyzed in triplicate.

Experiment No. 2: The purpose of this experiment was to ascertain the levels of Tween 80 in leaves of fieldgrown plants during the first 24 hours after treatment. Field-grown plants were treated with a preparation containing $4 \%$ of the 1 -octanol plus 1-decanol formulation and $1 \%$ of Tween 80 . Top and bottom leaves and stalks (upper half) were taken from four plants in four replicates and composited just after treatment ( 0 -time) and after 3,6 and 24 hours. Plants which received no treatment were used as controls.

Experiment No. 3: This experiment was conducted to compare residue levels of Tween 80 applied to fieldgrown plants at two dosages. The plants were treated with preparations containing $2.7 \%$ and $5.4 \%$ of the 1-octanol plus 1-decanol formulation and $0.68 \%$ and $1.36 \%$ of Tween 80 . At the time of harvest (14 days after treatment) and after air curing was completed, top and bottom leaves were taken from three plants and analyzed separately. Plants which received no treatment were used as controls.

All samples were freeze-dried, ground to pass a 40-mesh screen in a Wiley mill, and stored at $15^{\circ} \mathrm{C}$ until analyzed.

\section{Analytical procedure}

The hydrophilic characteristic of Tween 80 is supplied by the free hydroxyl groups in the mixed-function (oleic acid esters and polyoxyethylene ethers) derivatives of sorbitol anhydride and free polyoxyethylene. The hydrophobic characteristic is supplied by the oleic acid moieties. Extraction was based upon these two characteristics and led to two fractions - one consisting of the mixed-function derivatives (hereafter called Tween 80 Esters) and the other consisting of free polyoxyethylene compounds (called Tween 80 free Polyols). Analysis of these fractions followed, and that of the Tween 80 Esters was based on the free polyols (ester-derived free polyols) formed when they were hydrolyzed. The tobacco sample $(3.0 \mathrm{~g})$ was extracted with a ternary mixture (ethyl acetate/ethanol/water $83 / 8 / 9(\mathrm{v} / \mathrm{v} / \mathrm{v}))$ in a Soxhlet apparatus for 96 hours. The Tween 80 Esters and free Polyols were then partitioned between ethyl acetate and water, so that the Tween 80 free Polyols were extracted into the water, and the Tween 80 Esters remained in the ethyl acetate fraction. The Tween 80 Esters were saponified by alcoholic $\mathrm{KOH}$, and the hydrolysate was neutralized by $\mathrm{HCl}$. The neutralized solution was partitioned between hexane and water so that the esterderived free polyols were contained in the water fraction. Both water fractions, one containing the Tween 80 free Polyols and the other containing the ester-derived free polyols, were purified separately by passing through a mixed-bed ion-exchange resin column (TMD- ${ }^{*}$, anion dyed) eluted with water. The colorless eluates were

\footnotetext{
* obtained from Illinois Water Treatnent Co, Rockford, Illinois, U.S.A.
}

treated so that the free polyols were precipitated as their barium phosphomolybdic complexes, which were then dissolved in concentrated sulfuric acid. Molybdenum in solution was then converted into the molybdenum thiocyanate complex, which is yellow-amber and was measured spectrophotometrically at $420 \mathrm{~m} \mu(9,10)$. Standard curves for Tween 80 free Polyols and Esters were prepared with data obtained for commercial Tween 80 (ICI America Inc.). This product was partitioned between ethyl acetate and $10 \%$ aqueous sodium sulfate. Using the inorganic salt solution suppressed the solubility of the surfactant and inhibited emulsion formation. The Tween 80 free Polyols in the sodium sulfate solution were then extracted with alcohol. Next, both the alcohol extract of Tween 80 free Polyols and the ethyl acetate extract of Tween 80 Esters were evaporated and the residues weighed. A weighed portion of the residue consisting of the Tween 80 Esters was hydrolyzed, and the hydrolysate neutralized. This sample and a weighed portion of the residue consisting of the Tween 80 free Polyols were separately purified with the mixed-bed ion-exchange resin TMD-8 column. Then the purified samples were each diluted to four different concentrations; and these dilutions, together with a control blank, were analyzed as described for the tobacco samples. Since the absorbance follows Beer's Law, the calculated absorptivity values for various concentrations were observed to be approximately the same. An average absorptivity value is used for sample calculations.

\section{RESULTS AND DISCUSSION}

Experiment No. 1 (Table 1): The levels of Tween 80 Esters and free Polyols in top leaves treated with the sucker-control spray containing $1 \%$ Tween 80 were reduced by nearly $50 \%$ during the first week after treatment. No further reduction was seen during the next week (days 7 to 14) for either the 'Tween 80 Esters or free Polyols. During the curing period the level of Tween 80 Esters decreased significantly between days 28 and 32, and then remained unchanged. The level of the free polyols in the top leaves remained unchanged throughout the curing period. For the bottom leaves, neither the ester level nor the free polyol level decreased significantly during the entire 46-day growing and curing period. At the end of the curing season, the bottom leaves contained about half as much Tween 80 Ester and free Polyol residues as the top leaves. Differences in residues between the top leaves and bottom leaves are considered to have been due to the technique of applying the contact-type sucker-control agent. It was applied so that the uppermost leaves received the largest portion of the chemical spray, but all leaves most likely received some spray due to plant shape and spray run-off from leaf to leaf.

Experiment No. 2 (Table 2): During the first 24 hours after treating tobacco plants with a sucker-control spray 
containing $1 \%$ Tween 80 , the bottom leaves contained considerably less total Tween 80 residues (Tween 80 Esters plus free Polyols) than the top leaves (ca. $400 \mathrm{ppm}$ for top vs. ca. $50 \mathrm{ppm}$ for bottom). This finding is consistent with results obtained in Experiment No. 1. Also, the levels of Tween 80 Esters and free Polyols in the top leaves decreased by $69 \%$ and $51 \%$, respectively. The decrease in esters was greatest between hours 6 and 24, whereas the decrease in free polyols was greatest between hours 0 and 3. The levels of Tween 80 Esters and free Polyols in the bottom leaves remained unchanged, in agreement with the results of Experiment No. 1. In contrast to leaves, the upper half of stalks accumulated significant amounts of the Tween 80 Esters and free Polyols during the 24-hour period. Smith and Foy (11) reported that "C-labeled oxyethylene and acid materials applied on a bean plant moved slowly away from the treated spot. The amount of material that moved, however, represented only $1.3 \%$ to $3.1 \%$ of the total over a 4-day period. There may have been a greater movement of residue from leaves to stalks in our study, which showed Tween 80 Esters increasing from $294 \mathrm{ppm}$ to $690 \mathrm{ppm}$ and free Polyols increasing from $373 \mathrm{ppm}$ to $635 \mathrm{ppm}$. Likely, the increases were not due to a surface movement of Tween 80 from leaves to the stalk. Perhaps Tween 80 per se or its metabolites were translocated from the leaves to the stalk after being absorbed.

Experiment No. 3 (Table 3): The levels of Tween 80 Esters in both top and bottom leaves, and in both green and cured leaves, were significantly higher when Tween 80 was applied at $1.36 \%$ than at $0.68 \%$. There were also higher levels of 'Tween 80 free Polyols in green and cured bottom leaves, but not in top leaves due to the higher concentration of Tween 80 applied. Overall, top leaves contained more residues than bottom leaves. However, the average level of Tween 80 residues in bottom leaves was nearly twice as high for the $1.36 \%$ than for the $0.68 \%$ application rate (ca. 92 vs. ca. $202 \mathrm{ppm}$ ). For top leaves, the difference in residue levels between the two application rates was not so great (ca. $196 \mathrm{ppm}$ for $0.68 \%$ vs. ca. $267 \mathrm{ppm}$ for $1.36 \%$ application rate). Hagen, Clagett and Halgeson (12) showed that the butyl ester of 2,4-dichlorophenoxyacetic acid was hydrolyzed in castor bean after application. Such a hydrolysis of esters can be mediated by plant enzymes. $S$ mith and Foy (11) applied ${ }^{14} \mathrm{C}$-labeled Tween 20 on the roots and leaves of several types of plants and recovered a number of ${ }^{14} \mathrm{C}$-labeled materials, as separated by Sephadex column chromatography, from various parts of the plants. The researchers indicated that metabolism and translocation had taken place. If Tween 80 Esters hydrolyze to free polyols in the plant as reported by Tso and Chu (8), those polyols (as well as the Tween 80 free Polyols) may rapidly move to various plant parts. Such a movement would explain the results of Experiment No. 2, i.e. the markedly lower levels of Tween 80 Polyols in lower leaves than in the top leaves and the concomitant increase in free polyols in the upper half of the stalks. To confirm such a concept, studies with labeled Tween 80 to follow its movement and that of its degradation products may need to be undertaken.

\section{SUMMARY}

Surfactant residues (Tween 80 Esters and Tween 80 free Polyols) were determined in Maryland tobacco treated with a fatty-alcohol-type sucker-control formulation. The levels of residues in leaves decreased throughout the growing and air-curing periods, but decreased the most during the first 24 hours after treatment. Factors affecting Tween 80 residue levels included dosage and location of leaves on the plant.

\section{ZUSAMMENFASSUNG}

Maryland-Tabak, der mit einem Geizenwachstumshemmstoff vom Fettalkoholtyp behandelt worden war, wurde auf Rückstände an oberflächenaktiven Substanzen (Tween-80-Ester und freie Polyole des Tween 80) untersucht. Im Blattgut nahmen die Rückstandsmengen die ganze Wachstumsperiode hindurch und während des gesamten ,air-curing"-Trocknungsprozesses, am stärksten jedoch in den ersten 24 Stunden nach Applikation der Mittel ab. Maßgebend für den Rückstandsgehalt waren u. a. die Applikationsdosis und die Position der Blätter an der Sproßachse der Tabakpflanze.

\section{RESUME}

On a cherché à déceler des résidus tensio-actifs (esters de Tween 80 et polyoles libres du Tween 80 ) sur du tabac du Maryland ayant été traité avec un inhibiteur du type alcool gras. Les quantités de résidus diminuèrent pendant toute la période de croissance et lors du processus de séchage *air-curing*, mais la baisse la plus importante fut cependant surtout constatée dans les premières 24 heures ayant suivi le traitement. Les facteurs ayant le plus influé sur la teneur en résidus furent, entre autres, la dose appliquée et la position des feuilles sur la tige.

\section{REFERENCES}

1. Steffens, G. L., T. C. Tso and D. W. Spaulding: Fatty alcohol inhibition of tobacco axillary and terminal bud growth; J. Agric. Food Chem. 15 (1967) 972-975.

2. Steffens, G. L., and H. M. Cathey: Selection of fatty-acid derivatives-surfactant formulation for the control of plant meristems; J. Agric. Food Chem. 17 (1969) 312-317. 
3. Steffens, G. L., D. W. Spaulding, F. Clark, Z. T. Ford, H. W. Lundy, J. D. Miles, M. J. Rogers, H. Seltmann and J. F. Chaplin: Regional tests with contact and systemic tobacco sucker control agent, I. Flue-cured tobacco; Tobacco Sci. 13 (1969) 113-116.

4. Steffens, G. L., D. W. Spaulding, W. O. Atkinson, C. E. Bortner, L. A. Link, B. C. Nichols, H. F. Ross, H. Seltmann and L. Shaw: Regional tests with contact and systemic tobacco sucker control agents, II. Burley tobacco; Tobacco Sci. 13 (1969) 117-120.

5. Spaulding, D. W., G. L. Steffens and J. H. Hoyert: Regional tests with contact and systemic tobacco sucker control agents, IV. Maryland Tobacco; Tobacco Sci. 14 (1970) 98-100.

6. Smith, H. C., L. A. Link, G. L. Steffens and W. $O$. Atkinson: Regional tests with contact and systemic tobacco sucker control agents, III. Firecured tobacco; Tobacco Sci. 15 (1971) 87-89.

7. Tso, T. C., H. Chu and D. W. DeJong: Residue levels of fatty compounds and surfactants as suckering agents on tobacco; Beitr. Tabakforsch. 8 (1975) 241-245.

8. Tso, T. C., and H. Chu: The fate of fatty compounds and surfactants used as sucker control agents on field tobacco; Beitr. Tabakforsch. 9 (1977) $58-62$.

9. Ellis, R., Jr., and R. V. Olson: Photometric determination of molybdenum by acetone reduction of the thiocyanate; Anal. Chem. 22 (1950) 328-330.
10. Stevenson, D. G.: The absorptiometric determination of a non-ionic detergent; Analyst 79 (1954) 504-507.

11. Smith, L. W., and C. L. Foy: Penetration and distribution studies in bean, cotton, and barley from foliar and root applications of 'Tween $20-\mathrm{C}^{14}$, fatty acid and oxyethylene labeled; J. Agric. Food Chem. 14 (1966) 117-122.

12. Hagen, C. E., C. O. Clagett and F. A. Helgeson: 2,4-Dichlorophenoxyacetic acid inhibition of castor bean lipase; Science 110 (1949) 115-119.

13. Duncan, D. B. : Multiple range and multiple F tests; Biometrics 11 (1955) 1-48.

\section{Acknowledgements}

We thank C. F. Smullin, ICI United States (Analytical Section, Cbemical Research Department), for providing methodology information and T. C. Tso for bis helpful suggestions.

Authors' address:

Tobacco Laboratory,

Agricultural Research Service, U.S. Department of Agriculture, Beltsville, Maryland, 2070S, U.S. A. 